\title{
Quantification of caveolin isoforms using quantitative real-time RT-PCR, and analysis of promoter CpG methylation of caveolin-1 $\alpha$ in human $T$ cell leukemia cell lines
}

\author{
YUICHIRO TSUII ${ }^{1}$, TOSHIMASA NAKAGAWA ${ }^{2}$, MICHIYO HATANAKA $^{2,4}$, TOHRU TAKEUCHI $^{3}$, \\ ERIKO MATSUMOTO ${ }^{4}$, HIROSHI TAKENAKA ${ }^{1}$ and AKIRA SHIMIZU ${ }^{2}$

\begin{abstract}
Departments of ${ }^{1}$ Otolaryngology, and ${ }^{2}$ Clinical Pathology; ${ }^{3}$ First Department of Internal Medicine, Osaka Medical College, Daigakumachi Takatsuki 569-8686; ${ }^{4}$ Department of Medical Technology, Kobe-Tokiwa College, 2-6-2 Ohtani-cho Nagata-ku, Kobe 653-0838, Japan
\end{abstract}

Received April 3, 2006; Accepted May 30, 2006

\begin{abstract}
Caveolin-1, an essential structural component of caveolae, functions as a negative regulator for signal transduction and has been suggested to be a candidate tumor suppressor. Lack of caveolin-1 expression has been implicated in the pathogenesis of oncogenic cell transformation and tumorigenesis in many cancers. On the other hand, overexpression has also been associated with tumor progression and metastasis in prostate cancers. Hence, alteration of caveolin-1 expression has been proposed as a clinical marker for diagnosis and prognosis in various cancers. For precise analyses of the caveolin expression in human $\mathrm{T}$ cell leukemia cell lines, we measured the mRNA levels of caveolin isoforms, caveolin- $1 \alpha,-1 \beta,-2$, and -3 with real-time RT-PCR using external standards for each isoform. In the panel of human $\mathrm{T}$ cell leukemia cell lines tested, four cell lines expressed caveolin- $1 \alpha,-1 \beta$ and -2 , but not -3 , which was consistent with the protein levels. The expression profiles in most cell lines are caveolin- $1 \alpha>$ caveolin- $1 \beta>$ caveolin- 2 . Two cell lines did not express either of the caveolin mRNAs. Methylation analyses for the $\mathrm{CpG}$ sites in the promoter region of a positive and a negative cell line did not show a clear correlation with the expression status, suggesting that mechanisms other than $\mathrm{CpG}$ methylation are involved in the regulation of caveolin- $1 \alpha$ expression in human $\mathrm{T}$ cell leukemia cell lines.
\end{abstract}

\section{Introduction}

Caveolae are 50-100 $\mathrm{nm}$ invaginations that represent a cholesterol/glycosphingolipid-enriched microdomain of the

Correspondence to: Dr Michiyo Hatanaka, Department of Medical Technology, Kobe-Tokiwa College, 2-6-2 Ohtani-cho Nagata-ku, Kobe 653-0838, Japan

E-mail:mhatanaka@kobe-tokiwa.ac.jp

Key words: quantitative real-time RT-PCR, caveolin isoforms, promoter methylation, human $\mathrm{T}$ cell leukemia cell lines plasma membranes $(1,2)$. Although they were originally implicated in cellular transport processes $(3,4)$, they also participate in signal transduction-related events, including cell adhesion, growth and survival. They function as a center for signal transduction to compartmentalize and concentrate signaling molecules within a distinct region of the plasma membranes (1,5-7).

Caveolin is the major structural protein in caveolae. To date, multiple forms of caveolin, caveolin-1, -2 and -3 , have been identified (8). Caveolin-1 and -2 consist of two isoforms, $\alpha$ and $\beta$, the $\alpha$-isoform having additional amino acids at the $\mathrm{NH}_{2}$ terminus in both cases. It was originally thought that they were derived from alternate initiation during translation (9). However, recent evidence in the mouse showed that the two caveolin-1 isoforms are generated from distinct mRNAs, and that their production is regulated independently at the transcriptional level $(10,11)$. Caveolin-1 and -2 are expressed within most cell types, except for blood cells, as stable heterooligomeric complexes, while caveolin-3 is restricted to striated muscle cells and brain astroglial cells (12-14).

Caveolin-1 is known to serve as a scaffolding protein onto which signaling molecules are assembled. It directly interacts with the nonfunctional forms of the signaling molecules through a common $\mathrm{N}$-terminal domain, termed the caveolin scaffolding domain. Through this interaction, caveolin-1 negatively regulates the activation of many signaling molecules in caveolae, including endothelial nitric oxide synthase, heterotrimetric $\mathrm{G}$ protein and MAP kinase $(8,15,16)$. The function strongly suggests the possible role of caveolin-1 as a tumor suppressor. Consistent with this, the human caveolin gene was mapped to a suspected tumor locus (7q31.1) (17), which is often deleted in human cancers. In fact, caveolin-1 expression levels are decreased in many cancer cells $(18,19)$. However, in prostate and bladder cancer, caveolin- 1 expression is up-regulated $(20,21)$. Moreover, in prostate cancer, an increase in caveolin-1 expression is associated with tumor progression and metastasis (20), which is contradictory to the expected role of caveolin-1. Caveolin-1 expression is thus either up- or down-regulated depending on the cancer cell type. The molecular mechanisms involved in the two cases remain 
Table I. Primers and hybridization probes used in this study.

\begin{tabular}{|c|c|c|c|}
\hline Target & Sequence & Length (bp) & Genome localization \\
\hline \multicolumn{4}{|c|}{ Primers used for transcript quantification } \\
\hline Caveolin-1 $\alpha$ & $\begin{array}{l}\text { sense: 5'-CTG GGG GCA AAT ACG TAG A-3' } \\
\text { antisense: 5'-CTT GAC CAC GTC ATC GTT G-3' }\end{array}$ & 191 & $\begin{array}{c}5 \sim 23 \\
1607 \sim 1625\end{array}$ \\
\hline Caveolin-1ß & $\begin{array}{l}\text { sense: 5'-TTG CAT TTT TCC TCC CAC C-3' } \\
\text { antisense: 5'-CTT GAC CAC GTC ATC GTT G-3' }\end{array}$ & 232 & $\begin{array}{l}1393 \sim 1411 \\
1607 \sim 1625\end{array}$ \\
\hline Caveolin-2 & $\begin{array}{l}\text { sense: 5'-GCC CTC TTT GAA ATC AGC-3' } \\
\text { antisense: 5'-CAA GTA TTC AAT CCT GGC TC-3' }\end{array}$ & 241 & $\begin{array}{c}554 \sim 571 \\
6545 \sim 6554\end{array}$ \\
\hline Caveolin-3 & $\begin{array}{l}\text { sense: 5'-GCC CAG ATC GTC AAG GAT-3' } \\
\text { antisense: 5'-AGC AGC GTG GAC AAC AGA-3' }\end{array}$ & 209 & $\begin{array}{c}31 \sim 48 \\
11759 \sim 11776\end{array}$ \\
\hline G6PD & $\begin{array}{l}\text { sense: 5'-TGG ACC TGA CCT ACG GCA ACA GAT A-3' } \\
\text { antisense: 5'-GCC CTC ATA CTG GAA ACC C-3' }\end{array}$ & 257 & $\begin{array}{l}1732 \sim 1756 \\
1864 \sim 1884\end{array}$ \\
\hline \multicolumn{4}{|c|}{ Probes used for transcript quantification } \\
\hline Caveolin-1 & $\begin{array}{l}\text { fluorescein: 5'-ATG GCA GAC GAG CTG AGC GAG-3' } \\
\text { LC640: 5'-GTG TGC GCG TCG TAC ACT TGC T-3' }\end{array}$ & & $\begin{array}{l}1524 \sim 1544 \\
1546 \sim 1565\end{array}$ \\
\hline Caveolin-2 & $\begin{array}{l}\text { fluorescein: 5'-CCT TTT GTA AAG ACC TGC CTA ATG GTT C-3' } \\
\text { LC640: 5'-TCT TCC ATA TTG CTT GCA CTG AAG GC-3' }\end{array}$ & & $\begin{array}{l}680 \sim 707 \\
709 \sim 734\end{array}$ \\
\hline Caveolin-3 & $\begin{array}{l}\text { fluorescein: 5'-AAG ACG TGA TCG CAG AGC CTG TG-3' } \\
\text { LC640: 5'-ACG CCG TCA AAG CTG TAG GTG C-3' }\end{array}$ & & $\begin{array}{l}11662 \sim 11684 \\
11686 \sim 11707\end{array}$ \\
\hline G6PD & $\begin{array}{l}\text { fluorescein: 5'-TTT TCA CCC CAC TGC TGC ACC-3' } \\
\text { LC640: 5'-GCT TGG GCT TCT CCA GCT CAA TC-3' }\end{array}$ & & $\begin{array}{l}1886 \sim 1908 \\
1970 \sim 1988\end{array}$ \\
\hline \multicolumn{4}{|c|}{ Primers used for promoter methylation analysis } \\
\hline Region 1 & $\begin{array}{l}\text { sense: 5'-TGT GTA TTT TGT AAA TAT GGT ATA ATT TG-3' } \\
\text { antisense: 5'-CCA TCT CTA CCT TAA AAC ACA-3' }\end{array}$ & 353 & $\begin{array}{l}-878 \sim-850 \\
-547 \sim-526\end{array}$ \\
\hline Region 2 & $\begin{array}{l}\text { sense: 5'-GGA TAG GGT AGG ATT GTG GAT T-3' } \\
\text { antisense: 5'-TAT TTA CCC CCA AAC ATA CTA ACC-3' }\end{array}$ & 494 & $\begin{array}{l}-477 \sim-456 \\
\quad-7 \sim 17\end{array}$ \\
\hline
\end{tabular}

Nucleotide positions are based on sequences from GenBank database. Caveolin-1, HSA133269; caveolin-2, AF035752; caveolin-3, AF036365; G6PD, AF277315.

to be clarified, and the possible implication of caveolin-2 or -3 in cancer progression also remains elusive. Despite these situations, caveolin expression is expected to be applied as a novel marker for diagnosis and prognosis for progression in cancer.

Studies have been performed mainly by immunoblotting or immunohistochemistry, using antibodies to caveolin isoforms. Using a polyclonal antibody (pAb) to caveolin, we showed in the previous report the expression of caveolin-1 in human $\mathrm{T}$ cell leukemia cell lines (22), and this was the first demonstration of its expression in blood cells and cell lines. The expression levels of the isoforms were further determined by modified Western blotting (23). Notably, caveolin- $1 \alpha$ in the leukemia cells did not interact with the monoclonal antibody $(\mathrm{mAb})$ when it was tyrosine phosphorylated (23). Several mAbs to caveolin-1 were also shown to not interact with the $\alpha$ isoform in $\mathrm{v}$-src transformed cells (24). Thus, caveolin- $1 \alpha$ fails to interact with some mAbs in some cases. Therefore, to apply caveolin levels as markers for cancer diagnosis and prognosis, an alternative method that enables discriminative and quantitative determination of caveolin-1 $\alpha$ and other isoforms is crucial.

Recently, quantitative real-time RT-PCR has been increasingly used for quantification of caveolin mRNA (25-27). In many studies, mRNA levels were measured relative to a reference, such as an endogenous housekeeping gene or a normal control. In this study, we constructed DNA plasmids for each caveolin isoform as external standards and measured absolute mRNA levels of caveolin- $1 \alpha,-1 \beta,-2$ and -3 in a panel of human $\mathrm{T}$ cell leukemia cell lines. Using a panel of human leukemia cell lines with a variety of caveolin-expression levels, we showed that the mRNA levels were related to the protein expression and validated the effectiveness of the mRNA quantification for caveolin expression.

We also addressed the regulation mechanisms of caveolin$1 \alpha$ expression in human T cell leukemia cell lines. An analysis of the caveolin- $1 \alpha$ gene showed that the 5' promoter region has CpG-rich areas, known as $\mathrm{CpG}$ islands, and their hypermethylation is associated with decreased caveolin expression in prostate cancer (28) and breast cancer cell lines (29). We, 
therefore, conducted a detailed methylation analysis of the CpG sites in one of the positive cell lines, OKM-2T, and one of the negative cell lines, Jurkat-Cen. The fact that the methylation was not necessarily observed to be related to the expression status suggests that mechanisms other than methylation are involved in regulating cavolin-1 $\alpha$ expression in human $\mathrm{T}$ cell leukemia cell lines.

\section{Materials and methods}

Cells. Jurkat-Ida and Jurkat-Cen were cell lines maintained separately at Osaka Medical College and the Osaka Medical Center for Cancer and Cardiovascular Diseases, respectively. These cell lines were originally from the Japanese Cancer Research Resources Bank (JCRB). Adult T-cell leukemia cell lines, OKM-2T and OKM-3T, were from Dainippon Pharmaceutical Company. MT-1 and MT-2 were from JCRB. Cells (except for Jurkat-Ida) were maintained in RPMI-1640 supplemented with $10 \%$ fetal calf serum and antibiotics. Jurkat-Ida was maintained in the culture medium above with $20 \%$ fetal calf serum. Cultures were incubated in a $5 \% \mathrm{CO}_{2} /$ $95 \%$ air atmosphere at $37^{\circ} \mathrm{C}$.

Western blotting. Cells grown in suspension culture were washed with Dulbecco's phosphate-buffered saline (D-PBS) and were solubilized using a two-step procedure described previously (23). Caveolin isoforms were detected by modified Western blotting, as described previously (23). In this method, caveolin isoforms were firstly immunoprecipitated with a polyclonal antibody (pAb) to caveolin, which enabled the sensitive detection of caveolin isoforms, especially of caveolin-1 (23). Then, proteins were fractionated by $12 \%$ SDS-polyacrylamide gel electrophoresis and transferred to polyvinylidene difluoride (PVDF) membranes. Caveolin isoforms were probed by isoform-specific mAbs and visualized by blotting with horseradish peroxidase-conjugated secondary Abs using the ECL plus system (Amersham Biosciences). The $\mathrm{pAb}$ to caveolin and mAbs specific for caveolin-1 (clone 2297), -2 (clone 65) or -3 (clone 26) were obtained from BD Transduction Laboratories. For semi-quantification of the caveolin isoforms, the blots were photocopied on paper and the corresponding bands to each isoform were cut out and weighed.

Quantitative analysis of caveolin isoforms by real-time PCR total RNA isolation and cDNA synthesis. Cells grown in suspension culture were washed with Dulbecco's phosphatebuffered saline (D-PBS). Total RNA was isolated using an RNeasy mini kit (Qiagen) according to the manufacturer's instructions. The concentration and purity of the mRNA was evaluated by the absorbance at 260 and $280 \mathrm{~nm}$. RNA was reverse-transcribed into cDNA using Omniscript (Qiagen) with Random Primers (Invirogen) and was then used for quantification.

Primers and probes. Primers and hybridization probes (Table I) were delivered by Nihon-idenshi. To achieve the discriminative detection of caveolin-1 $\alpha,-1 \beta,-2$ and -3 mRNA, the primers designed to amplify regions specific for each caveolin isoform (Table I) were used. All of the primers used were intron-
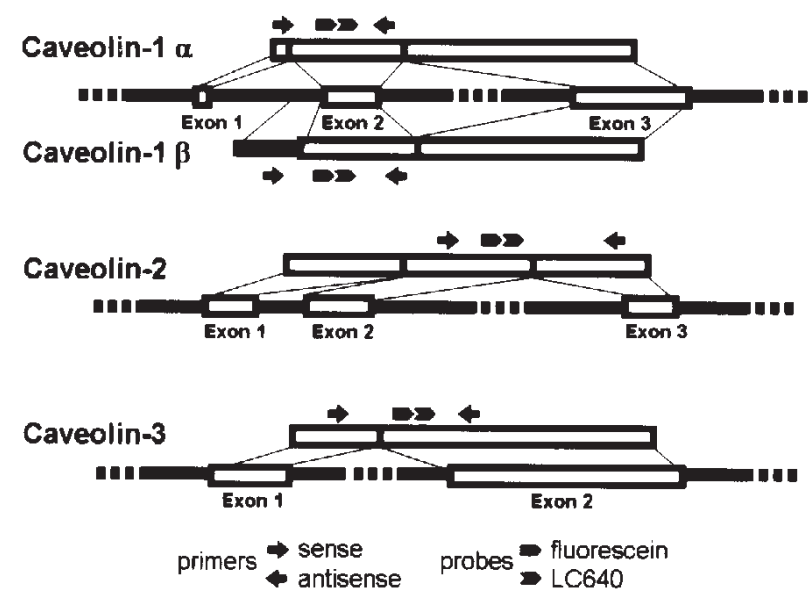

Figure 1. Positions of primers and probes for quantification of caveolin isoforms by real-time RT-PCR.

spanning primers and prevented the amplification of genomic DNA. The hybridization probes consisted of two different oligonucleotides that bind to specific internal sequences of the amplified fragments during the annealing phase of PCR cycles in such an order that the donor-probe (3'-fluorescein) and the acceptor-probe (5'-LC Red 640) hybridize head-totail in close proximity (1-5 nucleotides). The hybridization generates a significant increase in fluorescence proportional to the amount of starting templates (Fig. 1).

Plasmid standards. To determine the absolute copy number of the targeted transcripts, the cloned plasmid cDNAs for caveolin isoforms and glucose-6-phosphate dehydrogenase (G6PD) were used to generate calibration curves. The plasmids were obtained by transfecting corresponding template cDNAs to JM 109 high-efficiency competent cells (Promega). The cells were grown overnight at $37^{\circ} \mathrm{C}$ on Lauria-Banani (LB) plates containing $0.15 \mathrm{mM}$ ampicillin, $0.5 \mathrm{mM}$ IPTG and $0.2 \mathrm{mM}$ X-Gal. Cloned and purified [using Wizard columns (Promega)] plasmids were linearized with EcoRI and it was checked that they generated the proper signals by PCR using the primers in Table I. The quality and the concentration of the plasmids were evaluated by their absorbance at 260 and $280 \mathrm{~nm}$. The copy numbers of each plasmid standard were calculated using the Avogadro constant and the size of the plasmids. To generate the standard curves, the plasmid standards were serially diluted in 1:10 steps. Usually, a range from $10^{5}$ to $10^{2}$ copies was used.

Quantitative real-time RT-PCR. The LightCycler system (Roche Diagnosis) was used for amplification and data collection, as previously reported (30). Quantitative PCR was performed in a total reaction volume of $20 \mu 1$ per capillary for the LightCycler format. Each $20-\mu 1$ reaction volume contained $2 \mu 11 \mathrm{x}$ FastStart DNA master hybridization probes mix (Roche Diagnostics), $2 \mathrm{mM} \mathrm{MgCl}_{2}, 0.5 \mu \mathrm{M}$ of each primer, $0.2 \mathrm{mM}$ of each hybridization probe and $1 \mu 1$ plasmid standard $\left(10^{5}\right.$ to $10^{2}$ copies $)$ or cDNA. In every run, a negative control (water instead of cDNA) was included to check for cross contamination. Amplification was performed under the following conditions: initial heating to $95^{\circ} \mathrm{C}$ for 


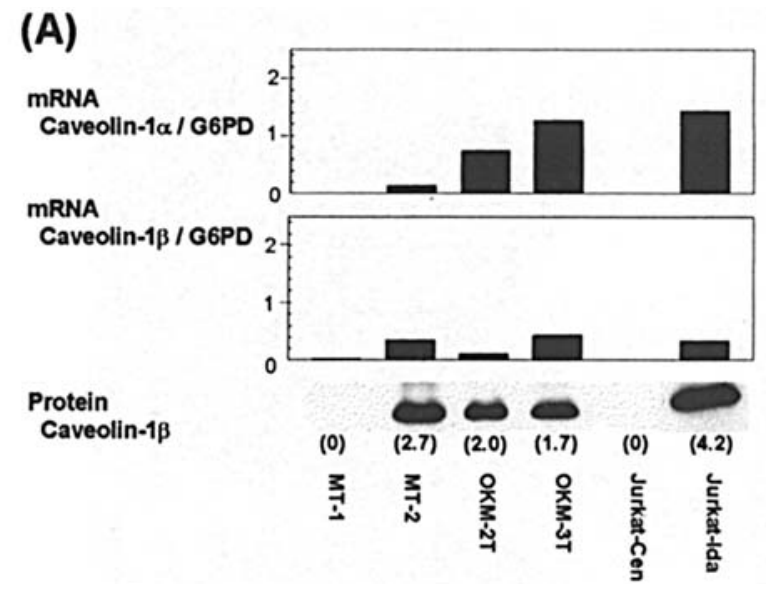

(B)

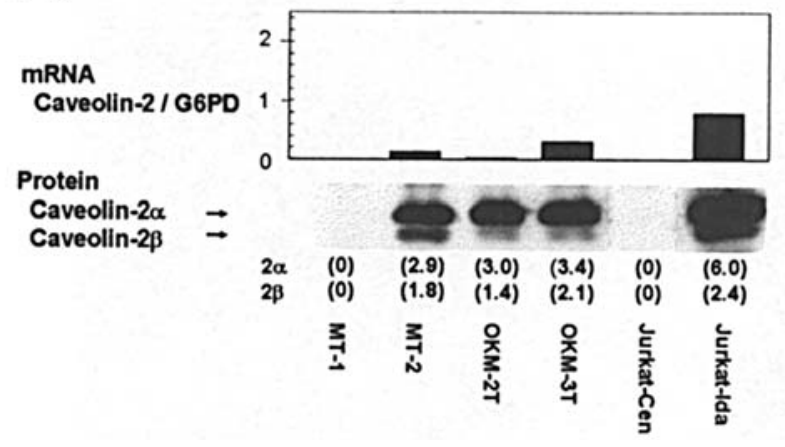

(C)

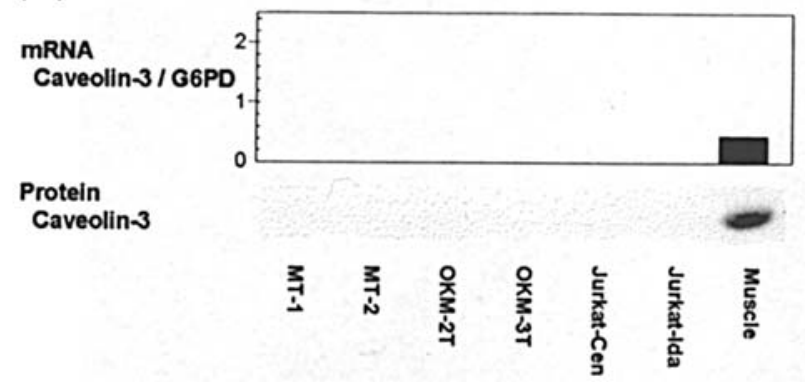

Figure 2. mRNA levels of caveolin isoforms by real time RT-PCR. Caveolin-1 $\alpha$ and -1ß (A), caveolin-2 (B) and caveolin-3 (C). Quantitative real-time RT-PCR was performed as described in the Materials and methods. Levels of caveolin- 2 mRNA represent caveolin-2 $\alpha$ plus $-2 \beta$ mRNA. Isoformspecific mRNA levels were determined by external standards and were normalized with an internal standard, G6PD. For reference, protein levels of caveolin isoforms determined by Western blot analyses were shown. For semi-quantification, blots photocopied on paper were cut and weighed, and shown as arbitrary units in parentheses. Caveolin- $1 \alpha$ was not detected by $\mathrm{mAb}$ to caveolin-1, because of phosphorylation at the tyrosine residue(s) in human T cell leukemia cell lines (23).

$10 \mathrm{~min}$, then 40 cycles at $95^{\circ} \mathrm{C}$ for $15 \mathrm{sec}, 60^{\circ} \mathrm{C}$ for $15 \mathrm{sec}$ and $72^{\circ} \mathrm{C}$ for $15 \mathrm{sec}$. The ratio of the signals measured in channel $2 /$ channel 1 was used to calculate the crossing point values. The crossing point value represents the cycle number in which the fluorescence increases for the first time above a threshold value.

Methylation analysis by bisulfite-PCR-genomic sequencing DNA isolation and bisulfite treatment. DNA was isolated from human leukemia cell lines, Jurkat-Cen and OKM-2T, using SepaGene (Sankoujunyaku) according to the manufacturer's instructions. DNA was treated with bisulfite to convert nonmethylated cytosines (C) to uracils (U) and was ultimately detected as thymidines (T) after PCR amplification. The bisulfite reaction was performed as previously reported (31). Briefly, $1 \mu \mathrm{g}$ of genomic DNA in water $(50 \mu \mathrm{l})$ was denatured with $5.5 \mu \mathrm{l}$ of $2 \mathrm{~N} \mathrm{NaOH}$ for $10 \mathrm{~min}$ at $37^{\circ} \mathrm{C}$. Then, $30 \mu \mathrm{l}$ of $10 \mathrm{mM}$ hydroquinone (Sigma) and $520 \mu \mathrm{l}$ of $3.6 \mathrm{M}$ sodium bisulfite (Sigma), pH 5.0, both freshly prepared, were added and mixed. Samples were incubated under mineral oil at $50^{\circ} \mathrm{C}$ for $16 \mathrm{~h}$. The modified DNA was purified using the Wizard DNA purification resin (Promega) according to the manufacturer's instruction. The samples were then desulfonated with $0.3 \mathrm{M} \mathrm{NaOH}$ for $5 \mathrm{~min}$ at room temperature, ethanol precipitated, resuspended in water, and used as templates in PCR reactions for sequencing analyses.

PCR amplifications and sequencing. PCR amplifications were performed in 50- $\mu 1$ reaction mixtures containing $2 \mu 1$ of bisulfite-modified genomic DNA, $200 \mu \mathrm{M}$ dNTP, $1 \mu \mathrm{M}$ of each respective primer, $3.5 \mathrm{mM} \mathrm{MgCl}$, and 2 units FastStart Taq DNA polymerase (Roche). Reactions were carried out in Mastercycler gradient (Eppendorf) with a hot-start at $95^{\circ} \mathrm{C}$ for $10 \mathrm{~min}$, followed by 40 cycles of amplification (40 sec at $95^{\circ} \mathrm{C}, 40 \mathrm{sec}$ at $58^{\circ} \mathrm{C}$, and $1 \mathrm{~min}$ at $72^{\circ} \mathrm{C}$ ) and a final 10 -min extension at $72^{\circ} \mathrm{C}$. The primers shown in Table I were used to amplify bisulfite-modified DNA (28). These primers amplify a 353-bp sequence containing 7 CpGs in region 1, and 494-bp sequences containing $28 \mathrm{CpGs}$ in region 2 , respectively. Each PCR product was run on $1.5 \%$ agarose gel and stained with ethidium bromide. The bands were cut from the gel and the PCR products were extracted using a SpinPrep Gel DNA kit (Novagen), and were ligated to plasmids using a pGEM-T Easy VectorSystem (Promega) according to the manufacturer's instructions. The recombinant plasmids were transformed to competent JM109 cells and cloned as described above. Ten clones from Jurkat-Cent and OKM-2T, respectively, were amplified and purified using Wizard columns (Promega).

The sequence reaction was carried out with a DYEnamic ET terminator cycle sequencing kit (Amersham Boisciences). Samples were sequenced with an ABI PRISM 310 genetic analyzer (PE Biosystems).

\section{Results}

Quantitative analysis of caveolin-1 $\alpha,-1 \beta,-2$ and -3 mRNA expression by real-time RT-PCR. Although two isoforms of caveolin-1, $\alpha$ and $\beta$, had been thought to be generated by alternate initiation from the same mRNA during translation (9), studies in mice revealed that caveolin- $1 \alpha$ was predominantly encoded by an alternative mRNA derived from a promoter in intron $1(10,11)$. Since the same mechanism was shown to be operative in humans (25), we used two sets of primers that amplify caveolin- $1 \alpha$ and $-1 \beta$, respectively. For caveolin- $2 \beta$, the generation mechanism remained unknown, although the same mechanism was suggested to be operative (25). In the present study, we used primers for caveolin-2 in exon 2 , so that both caveolin- $2 \alpha$ and $-2 \beta$ would be amplified simultaneously. Absolute copy numbers of the targets were determined according to external standard curves of the constructed DNA plasmids for each caveolin isoform. The absolute values 
Table II. Profiles of mRNA levels of caveolin isofoms in human leukemia cell lines.

\begin{tabular}{ll}
\hline Leukemia cell lines & \multicolumn{1}{c}{ Levels of caveolin mRNA } \\
\hline MT-1 & $\approx 0$ \\
MT-2 & caveolin- $1 \beta>$ caveolin- $1 \alpha=$ caveolin-2 \\
OKM-2T & caveolin- $1 \alpha>$ caveolin- $1 \beta>$ caveolin-2 \\
OKM-3T & caveolin- $1 \alpha>$ caveolin- $1 \beta=$ caveolin-2 \\
Jurkat-Cent & $\approx 0$ \\
Jurkat-Ida & caveolin- $1 \alpha>$ caveolin- $2>$ caveolin-1
\end{tabular}

mRNA levels of caveolin-1 and -2 were marginal in MT-1 and MT-2. mRNA of caveolin-3 was not detected in any of the cell lines.

measured were set in relation to a copy number of endogenous G6PD expression. Fig. 2 shows thus normalized absolute mRNA levels of the caveolin isoforms in human leukemia cell lines. The cell lines that express caveolin proteins (MT-2, OKM-2T, OKM-3T and Jurkat-Ida) expressed transcripts of caveolin-1 $\alpha,-1 \beta$ and -2 . The levels of each transcript were diverse. OKM-2T, OKM-3T and Jurkat-Ida expressed higher mRNA levels of caveolin- $1 \alpha$ than $-1 \beta$. The $\alpha / \beta$ ratio varied from $2.9(\mathrm{OKM}-3 \mathrm{~T})$ to $6.2(\mathrm{OKM}-2 \mathrm{~T})$. MT-2 alone expressed a higher mRNA level of caveolin-1 $\alpha$ than $-1 \beta$. The mRNA

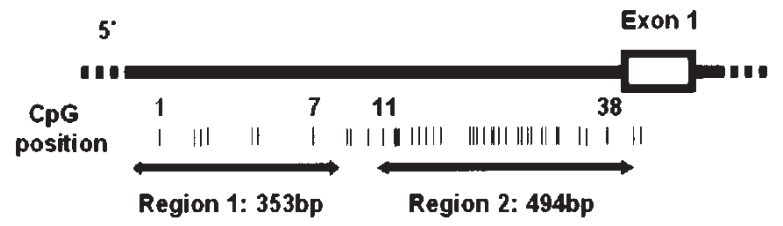

Figure 3. Map of $\mathrm{CpG}$ islands in the $5^{\prime}$ promoter region of caveolin-1 $\alpha$ Vertical lines show positions of $\mathrm{CpG}$ islands in the promoter region. Regions 1 and 2 contain 7 and $28 \mathrm{CpG}$ islands, respectively.

levels of caveolin-2 in caveolin-positive cell lines were lower than that of caveolin- $1 \alpha$ or $-1 \beta$, except that JurkatIda expressed a higher level of caveolin-2 than caveolin-1ß. Caveolin-3 mRNA was not detected at all in any of the cell lines. Caveolin-negative cell lines, MT-1 and Jurkat-Cen, expressed neither of the caveolin mRNAs; their expression profiles are summarized in Table II. The mRNA expression profiles of each caveolin isoform among the cell lines are basically similar to that of the protein expression.

Analysis of methylation of $C p G$ islands in caveolin-1a promoter. In the 900-bp upstream region of the caveolin- $1 \alpha$ translation start site (ATG), there are $38 \mathrm{CpG}$ islands, including the presence of $59 \%$ of $\mathrm{C}$ and $\mathrm{G}$ nucleotides (Fig. 3). In prostate cancer cells, $\mathrm{CpG}$ positions 1-7 and 11-28 were reported to be more methylated than normal prostate cells (28). To determine whether hypermethylation of the $\mathrm{CpG}$ sites is implicated in

\section{Jurkat-Cent}

\begin{tabular}{|c|c|c|c|c|c|c|c|c|c|c|c|c|c|c|c|c|c|c|c|c|c|c|c|c|c|c|c|c|c|c|c|c|c|c|c|}
\hline & \multicolumn{7}{|c|}{ Region 1} & \multicolumn{28}{|c|}{ Region 2} \\
\hline $\begin{array}{c}C_{\mathrm{p} G} \\
\text { position }\end{array}$ & 1 & 2 & 3 & 4 & 5 & 6 & 7 & 1 & \begin{tabular}{l|} 
\\
2
\end{tabular} & $\begin{array}{l}1 \\
3\end{array}$ & $\begin{array}{l}1 \\
4\end{array}$ & \begin{tabular}{l|}
1 \\
5
\end{tabular} & \begin{tabular}{l|}
1 \\
6
\end{tabular} & $\begin{array}{l}1 \\
?\end{array}$ & $\begin{array}{l}1 \\
8\end{array}$ & $\begin{array}{l}1 \\
9\end{array}$ & \begin{tabular}{l|}
2 \\
0
\end{tabular} & \begin{tabular}{|l|}
2 \\
1
\end{tabular} & $\begin{array}{l}2 \\
2\end{array}$ & \begin{tabular}{l|}
2 \\
3
\end{tabular} & $\begin{array}{l}2 \\
4\end{array}$ & $\begin{array}{l}2 \\
5\end{array}$ & $\begin{array}{l}2 \\
6\end{array}$ & $\begin{array}{l}3 \\
?\end{array}$ & $\begin{array}{l}2 \\
8\end{array}$ & \begin{tabular}{l|}
2 \\
9
\end{tabular} & $\begin{array}{l}3 \\
0\end{array}$ & \begin{tabular}{l|}
3 \\
1
\end{tabular} & \begin{tabular}{l|}
3 \\
2
\end{tabular} & \begin{tabular}{|l|}
3 \\
3
\end{tabular} & \begin{tabular}{l|}
3 \\
4
\end{tabular} & \begin{tabular}{|l|}
3 \\
5
\end{tabular} & \begin{tabular}{l|}
3 \\
6
\end{tabular} & \begin{tabular}{l|l}
3 \\
7
\end{tabular} & 3 \\
\hline Clone 1 & 0 & 0 & 1 & $\mathrm{O}$ & 0 & 0 & 0 & 0 & 0 & 0 & 0 & 0 & 0 & O) & O & 0 & 0 & 0 & 0 & 0 & 0 & 0 & 0 & 0 & 0 & 0 & 0 & 0 & O & 0 & 0 & 0 & 0 & 0 & 0 \\
\hline Clone 2 & 0 & 0 & 0 & 0 & 9 & 9 & 0 & 0 & O & 0 & 0 & 0 & 0 & 0 & o & 0 & 0 & 0 & 0 & 0 & 0 & o & 0 & 0 & 0 & 0 & 0 & 0 & o & 0 & 0 & 0 & o & 0 & \\
\hline Clome 3 & 0 & 1 & 0 & 0 & 0 & 9 & 0 & 0 & 0 & 0 & 0 & 0 & 0 & 9 & 0 & 0 & 0 & 0 & 0 & 0 & 0 & 0 & 0 & 0 & 0 & o & 0 & 0 & 0 & o & 0 & 0 & o & 0 & 0 \\
\hline Clome 4 & 9 & 0 & - & $\mathrm{O}$ & 0 & 0 & 0 & 0 & o & 0 & 이 & 9 & 이 & 0 & 0 & 0 & $\mathrm{O}$ & 0 & 0 & 0 & 0 & of & O & 0 & 0 & 0 & 0 & 0 & o & 0 & 0 & 0 & o & 0 & 0 \\
\hline Clome 5 & 9 & 9 & 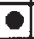 & 9 & 9 & 0 & 9 & 0 & 0 & 0 & 0 & 9 & 0 & 0 & 0 & 0 & 0 & 0 & 0 & 0 & $\mathrm{O}$ & of & 0 & 0 & 0 & 0 & o & 0 & o & 0 & 0 & o & o & 0 & $\bar{O}$ \\
\hline Clome 6 & 0 & 0 & e & 0 & 9 & 9 & 0 & 0 & 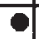 & 0 & 0 & 9 & 0 & 0 & 0 & 0 & 0 & 0 & 0 & 0 & 0 & o) & 0 & 0 & 0 & 0 & 0 & 0 & 0 & 0 & 0 & o & 0 & 0 & 0 \\
\hline Clome ? & 0 & 9 & 0 & 9 & 0 & $\overline{0}$ & 0 & e & o & 0 & 0 & 0 & 0 & 0 & 0 & 9 & 0 & 0 & 0 & 0 & 0 & o & 0 & 0 & 0 & 0 & O & 0 & o & \begin{tabular}{l|}
0 \\
\end{tabular} & 0 & 0 & 0 & 0 & 0 \\
\hline Clone 8 & 0 & 0 & 9 & 0 & $\overline{0}$ & $\overline{0}$ & 0 & 0 & 9 & 0 & O & o & 0 & of & of & O & 0 & 0 & 0 & o & 0 & 0 & 0 & 0 & 0 & 0 & o & 0 & 0 & 0 & 0 & o & O & 0 & 0 \\
\hline Clome 9 & 0 & 0 & 0 & 0 & 0 & 0 & 0 & 0 & 9 & 0 & 0 & 0 & 0 & 0 & O & 0 & 0 & 0 & 0 & o & 0 & o & 0 & 0 & 0 & 0 & 0 & 0 & 0 & 0 & 0 & o & 0 & O & 0 \\
\hline Clome 10 & 0 & 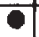 & 0 & 0 & 0 & 9 & 0 & 0 & $\theta$ & 0 & 0 & 0 & 0 & 0 & 0 & 0 & 0 & 0 & 0 & o & 0 & o & 0 & 0 & 0 & 0 & of & 0 & 0 & 0 & 0 & 0 & 0 & 0 & $\overline{0}$ \\
\hline
\end{tabular}

\section{OKM-2T}

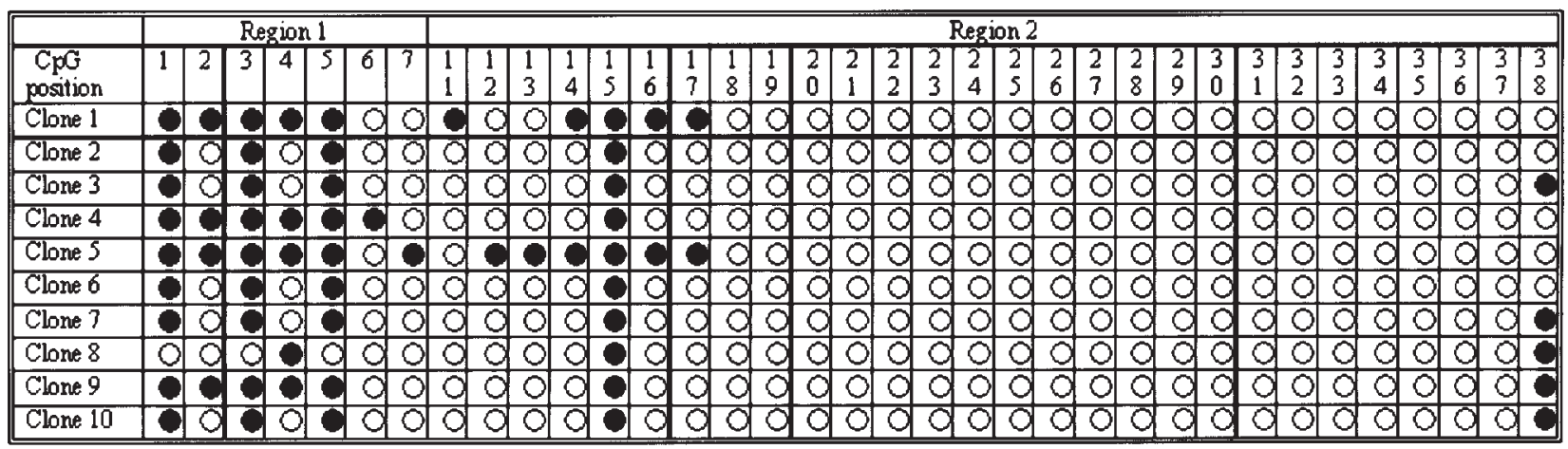

Figure 4. Methylation profiles of $\mathrm{CpG}$ position in region 1 and region 2 of caveolin-1 $\alpha$ promoter by bisulfite sequencing. Ten clones from Jurkat-Cen and OKM-2T were sequenced. Methylated residues $(\bullet)$, and unmethylated residues $(0)$. 
caveolin-1 expression in human $\mathrm{T}$ cell leukemia cell lines, promoter region 1 , containing $7 \mathrm{CpGs}$, and region 2 containing $28 \mathrm{CpGs}$, were analyzed using bisulfite-PCR-genomic sequencing. We determined the methylation frequency of the caveolin-1 $\alpha$ gene in 10 clones from a caveolin-1-positive cell line, OKM-2T, and compared it with that in 10 clones from a caveolin-1-negative cell line, Jurkat-Cen. The results are summarized in Fig. 4. The sites suggestive of a relation to the lack of caveolin- $1 \alpha$ expression were the first three CpGs in region 1, where they were fully methylated in Jurkat-Cen but unmethylated in some clones from OKM-2T. In region 2, the first $8 \mathrm{CpG}$ sites (position 11-18) were partially methylated, but the remaining sites were mostly unmethylated in both cell lines. Differences were observed at the fifth $\mathrm{CpG}$ (position 15), where it is fully methylated in clones from OKM-2T, but in only half of the clones from Jurkat-Cen, and at the last CpG (position 38), where one clone was methylated in Jurkat-Cen, and five clones in OKM-2T. The methylation profile, however, runs counter to the protein expression. Thus, overall marginal differences in the methylation status were observed between the two cell lines, but most of them did not correlate with caveolin-1 $\alpha$ expression. Therefore, mechanisms other than methylation are likely to regulate caveolin- $1 \alpha$ expression in human $\mathrm{T}$ cell leukemia cell lines.

\section{Discussion}

In the previous study we have detected caveolin isoforms in a panel of human $\mathrm{T}$ cell leukemia cell lines by modified Western blotting (23). Using these cell lines, we measured the absolute copies of mRNA using external standards of each isomer with real time RT-PCR. Our results demonstrated that all of the protein-positive cell lines expressed mRNA of caveolin-1 $\alpha$, $1 \beta$ and -2 , but not -3 , whereas the protein-negative cell lines expressed neither of the mRNAs. In some cases, the levels of mRNA and proteins were not proportional due to degradation of the proteins or the post-transcriptional regulations of mRNA. This was not the case in caveolin isoforms in the leukemia cell lines, and the mRNA was determined to be relatively consistent with the protein expression levels. By Western blotting, due to differences in the affinity of each antibody, the expression levels of the isoforms in each cell line were not comparable. This study showed that the mRNA expression level of caveolin-1 $\alpha$ overwhelmed other caveolin isoforms in all of the positive cell lines. Caveolin- $1 \alpha,-1 \beta$ and -2 were detected in those cell lines although their ratios varied depending on the cell lines, suggesting that similar regulation mechanisms are implicated in the expression of these isoforms. It is intriguing that even in the negative cell lines, their mRNA levels were not absolutely nil, but were marginally detected with increasing PCR cycles. In contrast, caveolin-3 mRNA was not detected at all. This suggests that caveolin-1 and -2 , but not -3 , may be inducible in some conditions. In fact, OKM-2T and MT-4 were originally identified as caveolinnegative cell lines (22), but had come to express caveolin-1 and -2, although not caveolin-3, during continuous subculture.

DNA methylation in the CpG-rich areas, known as a $\mathrm{CpG}$ island, is associated with gene silencing and has been shown to occur frequently in immortalized and transformed cells (32-34). The caveolin-1 $\alpha$ gene shows that the promoter has
$38 \mathrm{CpG}$ sites, and its hypermethylation was associated with decreased caveolin expression in breast cancer cell lines (29). Hypermethylation was also demonstrated in relation to caveolin expression in neuronal cells and small cell lung cancer $(35,36)$. In these cells, heavy methylation was found at the first seven CpGs in particular. In this study we analyzed the $35 \mathrm{CpGs}$ in caveolin-positive and -negative human $\mathrm{T}$ cell leukemia cell lines, and showed that methylation was observed mainly at the first seven CpGs in both cell lines. Among them, the sites suggestive of a relation to gene expression were the first three CpGs. Above all, the second $\mathrm{CpG}$ was methylated in all 10 clones from the caveolin-1-negative cell line, and in 4 out of 10 clones from the caveolin-1-positive cell line. Blood cells are unique for not expressing caveolins in the normal state. In lymphocytes, it was demonstrated that the first four CpGs were highly methylated (25). Since full methylation was shown at the second $\mathrm{CpG}$, similar to the negative leukemia cell line, this site might be the most suggestive for the regulation of caveolin-1 $\alpha$ expression in blood cells and cell lines. However, excepting this site, an obvious distinction was not observed between the positive and negative cell line, so we considered that lack of caveolin- $1 \alpha$ expression was not caused by methylation. Also, in follicular thyroid carcinoma and lung cancer, methylation was not correlated with caveolin-1 gene expression (25). Several mechanisms other than methylation were reported to be involved in the suppression of cavolin- $1 \alpha$ gene expression, including the loss of heterogeneity, myc, ETS proteins, and point mutation. Further studies are needed to elucidate the suppression mechanisms of caveolin- $1 \alpha$ and other caveolin isoforms in blood cells and cell lines.

Much remains to be elucidated about the molecular mechanisms of the caveolin-1 overexpression observed in prostate and bladder cancer. In these cases, overexpression induced cell activation and was associated with tumor progression and metastasis, which is apparently contradictory to the expected roles of caveolin-1. A similar situation may be typical in blood cells: caveolin-1 is not expressed in normal human blood cells, but is expressed in $\mathrm{T}$ cell leukemia cell lines with a highly activated phenotype. We have recently shown that the caveolin- $1 \alpha$ and $-2 \alpha$ expressed in these cell lines are tyrosine phosphorylated (23). The modification is likely to inactivate its function of scaffolding signaling molecules to caveolae, and lead to cell activation. Thus, not only the caveolin expression levels, but also their phosphorylation states are closely related to the tumor progression and metastasis. Therefore, the quantification of caveolin isoforms, together with information about their modification states in each cancer cell type, will make caveolin widely applicable as a marker for diagnosis, prognosis, and therapy in various cancers.

\section{References}

1. Parton RG and Simons K: Digging into caveolae. Science 269: 1398-1399, 1995.

2. Anderson RGW: The caveolae membrane system. Annu Rev Biochem 67: 199-225, 1998.

3. Anderson RG, Kamen BA, Rothberg KG and Lacey SW: Potocytosis: sequestration and transport of small molecules by caveolae. Science 255: 410-411, 1992.

4. Conner SD and Schmid SL: Regulated portals of entry into the cell. Nature 422: 37-44, 2003.

5. Galbiati F, Razani B and Lisanti MP: Emerging themes in lipid rafts and caveolae. Cell 106: 403-411, 2001. 
6. Anderson RG and Jacobson K: A role for lipid shells in targeting proteins to caveolae, rafts, and other lipid domains. Science 296: 1821-1825, 2002.

7. Carver LA and Schnitzer JE: Caveolae: mining little caves for new cancer targets. Nature Rev 3: 571-581, 2003.

8. Okamoto T, Schlegel A, Scherer PE and Lisanti MP: Caveolins, a family of scaffolding proteins for organizing 'preassembled signaling complexes' at the plasma membrane. J Biol Chem 273: 5419-5422, 1998

9. Scherer PE, Tang Z, Chun M, Sargiacomo M, Lodish HF and Lisanti MP: Caveolin isoforms differ in their N-terminal protein sequence and subcellular distribution. Identification and epitope mapping of an isoform-specific monoclonal antibody probe. J Biol Chem 270: 16395-16401, 1995.

10. Kogo H and Fujimoto T: Caveolin-1 isoforms are encoded by distinct mRNAs. Identification of mouse caveolin-1 mRNA variants caused by alternative transcription initiation and splicing. FEBS Lett 465: 119-123, 2000.

11. Kogo H, Aiba T and Fujimoto T: Cell type-specific occurrence of caveolin- $1 \alpha$ and $-1 \beta$ in the lung caused by expression of distinct mRNAs. J Biol Chem 279: 25574-25581, 2004.

12. Das K, Lewis RY, Scherer PE and Lisanti MP: The membranespanning domains of caveolins-1 and -2 mediate the formation of caveolin hetero-oligomers. Implications for the assembly of caveolae membranes in vivo. J Biol Chem 274: 18721-18728, 1999.

13. Scherer PE, Lewis RY, Volonté D, Engelman JA, Galbiati F, Couet J, Kohtz DS, van Donselaar E, Peters P and Lisanti MP: Cell-type and tissue-specific expression of caveolin-2. Caveolins 1 and 2 co-localize and form a stable hetero-oligomeric complex in vivo. J Biol Chem 272: 29337-29346, 1997.

14. Ikezu T, Ueda H, Trapp BD, Nishiyama K, Sha JF, Volonte D, Galbiati F, Byrd AL, Bassell G, Serizawa H, Lane WS, Lisanti MP and Okamato T: Affinity-purification and characterization of caveolins from the brain: differential expression of caveolin-1, -2 , and -3 in brain endothelial and astroglial cell types. Brain Res 804: 177-192, 1998.

15. Razani B, Schlegel A and Lisanti MP: Caveolin proteins in signaling, oncogenic transformation and muscular dystrophy. J Cell Sci 113: 2103-2109, 2000.

16. Williams TM and Lisanti PM: Caveolin-1 in oncogenic transformation, cancer, and metastasis. Am J Physiol Cell Physiol 288: C494-C506, 2005.

17. Engelman JA, Zhang XL and Lisanti MP: Genes encoding human caveolin-1 and -2 are co-localized to the D7S522 locus (7q31.1), a known fragile site (FRA7G) that is frequently deleted in human cancers. FEBS Lett 436: 403-410, 1998

18. Racine C, Bélanger M, Hirabayashi H, Boucher M, Chakir J and Couet J: Reduction of caveolin 1 gene expression in lung carcinoma cell lines. Biochem Biophys Res Comm 255: 580-586, 1999.

19. Wiechen K, Diatchenko L, Agoulnik A, Scharff KM, Schober H, Arlt K, Zhumabayeva B, Siebert PD, Dietel M, Schäfer R and Sers C: Caveolin-1 is down-regulated in human ovarian carcinoma and acts as a candidate tumor suppressor gene. Am J Pathol 159: 1635-1643, 2001

20. Yang G, Truong LD, Wheeler TM and Thompson TC: Caveolin-1 expression in clinically confined human prostate cancer: a novel prognostic marker. Cancer Res 59: 5719-5723, 1999.

21. Rajjayabun PH, Garg S, Durkan GC, Charlton R, Robinson MC and Mellon JK: Caveolin-1 expression is associated with highgrade bladder cancer. Urology 58: 811-814, 2001.
22. Hatanaka M, Maeda T, Ikemoto T, Mori H, Seya T and Shimizu A: Expression of caveolin-1 in human T cell leukemia cell lines. Biochem Biophys Res Comm 253: 382-387, 1998.

23. Tsuji Y, Hatanaka M, Maeda T, Seya T, Takenaka H and Shimizu A: Differential-expression and tyrosine-phosphorylation profiles of caveolin isoforms in human $\mathrm{T}$ cell leukemia cell lines. Int J Mol Med 16: 889-893, 2005.

24. Nomura R and Fujimoto T: Tyrosine-phosphorylated caveolin1: immunolocalization and molecular characterization. Mol Biol Cell 10: 975-986, 1999.

25. Aldred MA, Ginn-Pease ME, Morrison CD, Popkie AP, Gimm O, Hoang-Vu C, Krause U, Dralle H, Jhiang SM, Plass C and Eng C: Caveolin-1 and caveolin-2, together with three bone morphogenetic protein-related genes, may encode novel tumor suppressors down-regulated in sporadic follicular thyroid carcinogenesis. Cancer Res 63: 2864-2871, 2003.

26. Sagara Y, Mimori K, Yoshinaga K, Tanaka F, Nishida K, Ohno S, Inoue $\mathrm{H}$ and Mori M: Clinical significance of caveolin1, caveolin-2 and HER2/neu mRNA expression in human breast cancer. Br J Cancer 91: 959-965, 2004.

27. Abulrob A, Giuseppin S, Andrade MF, McDermid A, Moreno M and Stanimirovic D: Interactions of EGFR and caveolin-1 in human glioblastoma cells: evidence that tyrosine phosphorylation regulates EGFR association with caveolae. Oncogene 23: 6967-6979, 2004

28. Cui J, Rohr LR, Swanson G, Speights VO, Maxwell T and Brothman AR: Hypermethylation of the caveolin-1 gene promoter in prostate cancer. Prostate 46: 249-256, 2001.

29. Engelman JA, Zhang XL and Lisanti MP: Sequence and detailed organization of the human caveolin-1 and -2 genes located near the D7S522 locus (7q31.1). Methylation of a CpG island in the 5 ' promoter region of the caveolin-1 gene in human breast cancer cell lines. FEBS Lett 448: 221-230, 1999.

30. Kühne BS and Oschmann P: Quantitative real-time RT-PCR using hybridization probes and imported standard curves for cytokine gene expression analysis. Biotechniques 33: 1078-1084, 2002 .

31. Herman JG and Baylin SB: Methylation-specific PCR. In: Current Protocol in Human Genetics. Dracopoli NC, Haines JL, Korf BR, et al (eds). John Wiley \& Sons Inc., New York, pp10.6.1-10.6.10, 1998 .

32. Antequera F, Boyes J and Bird A: High levels of de novo methylation and altered chromatin structure at $\mathrm{CpG}$ island in cell lines. Cell 62: 503-514, 1990.

33. Herman JG, Latif F, Weng Y, Lerman MI, Zbar B, Liu S, Samid D, Duan DR, Gnarra JR, Linehan WM and Baylin SB: Silencing of the VHL tumor-suppressor gene by DNA methylation in renal carcinoma. Proc Natl Acad Sci USA 91: 9700-9704, 1994.

34. Merlo A, Herman JG, Mao L, Lee DJ, Gabrielson E, Burger PC, Baylin SB and Sidransky D: 5' CpG island methylation is associated with transcriptional silencing of the tumor suppressor p16/CDKN2/MTS1 in human cancers. Nat Med 1: 686-692, 1995

35. Zschocke J, Manthey D, Bayatti N, van der Burg B, Goodenough S and Behl C: Estrogen receptor $\alpha$-mediated silencing of caveolin gene expression in neuronal cells. J Biol Chem 277: 38772-38780, 2002.

36. Sunaga N, Miyajima K, Suzuki M, Sato M, White MA, Ramirez RD, Shay JW, Gazdar AF and Minna JD: Different roles for caveolin-1 in the development of non-small cell lung cancer versus small cell lung cancer. Cancer Res 64: 4277-4285, 2004. 